\title{
Serology- and Blood-PCR-Based Screening for Schistosomiasis in Pregnant Women in Madagascar-A Cross-Sectional Study and Test Comparison Approach
}

\author{
Tanja Hoffmann ${ }^{1,+}$, Imke Carsjens ${ }^{1,+}$, Raphaël Rakotozandrindrainy ${ }^{2}$, Mirko Girmann ${ }^{3}$ (D), \\ Njary Randriamampionona ${ }^{2}$, Oumou Maïga-Ascofaré ${ }^{4}$, Andreas Podbielski ${ }^{5, *}$, Andreas Hahn ${ }^{5}$ (D), \\ Hagen Frickmann $1,5, \ddagger$ and Norbert Georg Schwarz ${ }^{3, \ddagger}$
}

check for updates

Citation: Hoffmann, T.; Carsjens, I.; Rakotozandrindrainy, R.; Girmann,

M.; Randriamampionona, N.;

Maïga-Ascofaré, O.; Podbielski, A.; Hahn, A.; Frickmann, H.; Schwarz, N.G. Serology- and Blood-PCR-Based Screening for Schistosomiasis in Pregnant Women in Madagascar-A Cross-Sectional Study and Test Comparison Approach. Pathogens 2021, 10, 722. https://doi.org/ $10.3390 /$ pathogens 10060722

Academic Editor: Jose Muñoz Gutiérrez

Received: 24 April 2021

Accepted: 5 June 2021

Published: 8 June 2021

Publisher's Note: MDPI stays neutral with regard to jurisdictional claims in published maps and institutional affiliations.

Copyright: (c) 2021 by the authors Licensee MDPI, Basel, Switzerland. This article is an open access article distributed under the terms and conditions of the Creative Commons Attribution (CC BY) license (https:// creativecommons.org/licenses/by/ $4.0 /)$
1 Department of Microbiology and Hospital Hygiene, Bundeswehr Hospital Hamburg, 20359 Hamburg, Germany; tanja1hoffmann@bundeswehr.org (T.H.); imke.carsjens@gmx.de (I.C.); frickmann@bnitm.de (H.F.)

2 Department of Microbiology and Parasitology, University of Antananarivo, BP 566 Antananarivo, Madagascar; rakrapha13@gmail.com (R.R.); njrandriamampionona@gmail.com (N.R.)

3 Independent Researcher, 20095 Hamburg, Germany; microthewave@hotmail.com (M.G.); schwarznorbert@web.de (N.G.S.)

4 Infectious Disease Epidemiology Department, Bernhard Nocht Institute for Tropical Medicine Hamburg, 20359 Hamburg, Germany; maiga@bnitm.de

5 Institute for Medical Microbiology, Virology and Infectious Disease Epidemiology,

University Medicine Rostock, 18057 Rostock, Germany; hahn.andreas@me.com

* Correspondence: andreas.podbielski@med.uni-rostock.de; Tel.: +0049-381-494-5901

+ Both authors contributed equally to this work.

$\ddagger$ Both authors contributed equally to this work

Abstract: This work was conducted as a cross sectional study to define the disease burden of schistosomiasis in pregnant Madagascan women and to evaluate serological and molecular diagnostic assays. A total of 1154 residual EDTA blood samples from pregnant Madagascan women were assessed. The nucleic acid extractions were subjected to in-house real-time PCRs specifically targeting S. mansoni complex, S. haematobium complex, and African Schistosoma spp. on genus level, while the EDTA plasma samples were analyzed using Schistosoma-specific IgG and IgM commercial ELISA and immunofluorescence assays. The analyses indicated an overall prevalence of schistosomiasis in Madagascan pregnant women of $40.4 \%$, with only minor regional differences and differences between serology- and blood PCR-based surveillance. The S. mansoni specific real-time PCR showed superior sensitivity of $74 \%$ (specificity $80 \%$ ) compared with the genus-specific real-time PCR (sensitivity $13 \%$, specificity $100 \%$ ) in blood. The laborious immunofluorescence (sensitivity $\operatorname{IgM} 49 \%$, IgG $87 \%$, specificity IgM 85\%, IgG 96\%) scored only slightly better than the automatable ELISA (sensitivity IgM 38\%, IgG 88\%, specificity IgM 78\%, IgG 91\%). Infections with S. mansoni were detected only. The high prevalence of schistosomiasis recorded here among pregnant women in Madagascar calls for actions in order to reduce the disease burden.

Keywords: schistosomiasis; blood samples; Madagascar; pregnancy; test comparison; epidemiology

\section{Introduction}

Schistosomiasis is highly prevalent in Madagascar [1]. Especially in remote areas, signs of periportal fibrosis associated with Schistosoma (S.) mansoni infections, even in school children, indicate high infection pressure and pathogen load [2]. This is particularly important considering the fact that liver alterations are usually observed as long-term consequences of S. mansoni infections [3]. Considerable infection rates in Madagascan children have been confirmed by numerous epidemiological assessments [4,5]. Abundance of well-adapted freshwater snails as intermediate hosts [6-8], associated with measurable pathogen DNA levels in freshwater [9], support the transmission of Schistosoma spp. 
In Madagascar, S. haematobium, which is predominant in the Northern and Western regions of the island, is the major cause of urogenital schistosomiasis [10-14], potentially resulting in complications during pregnancy [15]. S. haematobium is generally assumed to be a relevant cause of obstetrical complications like ectopic pregnancy [16], preterm delivery, and reduced birth weight [17-19]. Indirect complications like altered immune responses or consequences of maternal anemia during pregnancy are discussed for newborns from mothers with S. mansoni infections as well [18,20-24].

So far, little is known about the epidemiology of schistosomiasis in Madagascan pregnant women. Between April and July 2010, a total of 1244 EDTA blood samples were collected and aliquots of each sample were subjected to urea pretreatment in order to stabilize nucleic acids within the samples. Afterwards, the samples were subjected to serological and PCR-assessment targeting a variety of pathogens, including plasmodiae, rickettsiae, Treponema pallidum, human immunodeficiency virus, cyclovirus, Zika virus, Dengue virus, Chikungunya virus, and Rift valley fever virus [25-30].

Next to microscopy and PCR from stool [4] as well as microscopy, PCR, and antigen testing from urine [31,32], schistosomiasis can also be detected by highly sensitive real-time PCR assays [33-35] from blood and previous infections by serology [36]. While serology is poorly suited to differentiate active from successfully cured schistosomiasis [36], recent assessments indicated steadily increasing cycle threshold values $(\mathrm{Ct})$ of real-time PCR in the course after successful treatment [37], making PCR potentially suitable as a marker for disease activity.

In this study, the above-mentioned residual materials from blood samples from Madagascan pregnant women were assessed for active or previous schistosomiasis by serology and PCR. The aims were both a general epidemiologic assessment and a comparative assessment of the applied diagnostic approaches. Thereby, determination of potential crossreactivity between anti-malaria-antibodies and anti-Schistosoma-antibodies [38], which was suggested from previous assessments [39-41], were considered. Finally, the diagnostic accuracy adjusted overall prevalence [42] was calculated considering the observed sensitivities and specificities of the test approaches.

\section{Results}

\subsection{Local Epidemiology}

After exclusion of 90 pregnant women (please see Appendix A for the geographic distribution), for whom the whole residual sample material was gone, the study population consisted of 1154 pregnant women from 6 different locations in Madagascar, 2 coastal, and 4 in the highlands (Figure 1). The median age was 25 in a right-skewed distribution and did not relevantly differ for the various study sites as detailed elsewhere [25-30]. Data on previous treatment for schistosomiasis were not available.

Samples from these 1154 pregnant women were investigated for Schistosoma spp.specific DNA using real-time PCR and for IgM and IgG antibodies against schistosomiasis using serological methods (ELISA and immunofluorescence). Three different real-time PCR assays were compared, one species-overarching assay targeting the ITS- 2 region for African Schistosoma spp. in general, one species-specific assay targeting the highly repetitive Dra1 region for S. haematobium complex, and a species-specific assay targeting the highly repetitive $S m 1-7$ region for $S$. mansoni complex. The latter two assays were run in a one-tube duplex approach. None of the S. haematobium PCRs were positive. The non-species-specific Schistosoma spp. PCR was positive in 5.5\% of the samples, while the more sensitive S. mansoni specific PCR was positive in $42.0 \%$ of the samples.

The highest proportions of positive PCR samples (69.1\%) were found in Ambositra, the highest study location (1280 m) (Table 1). Over all 6 sites, IgG seroprevalences were $37.3 \%$ with the immunofluorescence assay and $40.8 \%$ with the ELISA, while IgM seroprevalences were $28.5 \%$ with the immunofluorescence assay and $28.8 \%$ with the ELISA, respectively. Consistent with PCR results, the highest IgG-seroprevalence (71.1\%) was found in Ambositra. Only a weak to moderate association between altitude and schistosomiasis prevalence 
could be demonstrated for the assessed population in correlation analysis, while a clear-cut correlation could not be shown (Table 1).

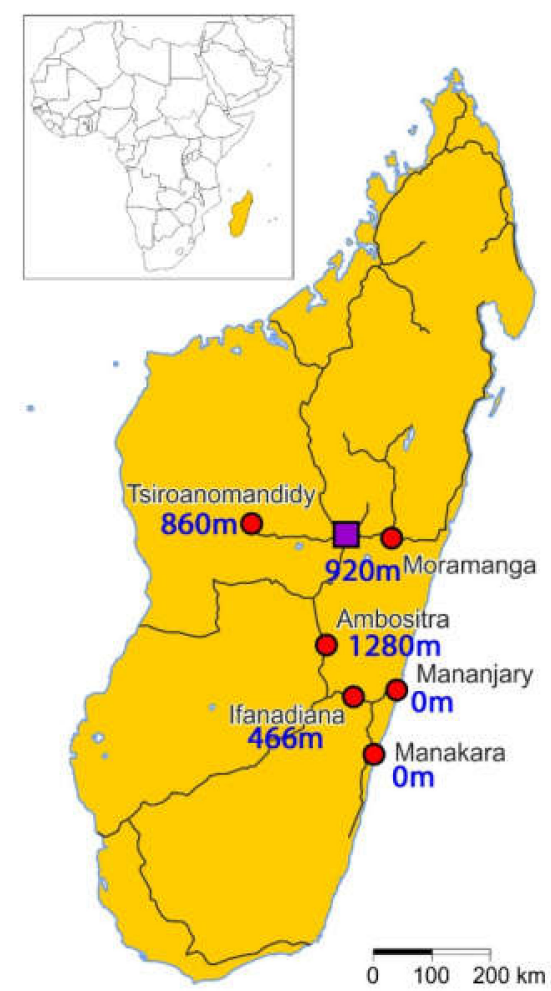

Figure 1. Map of Madagascar showing the 6 study locations and their altitude. The purple square is the capital Antananarivo; the dark lines represent main roads. The study found no signs of $S$. haematobium but demonstrated a presence of S. mansoni in all 6 locations [29].

Table 1. Test results for serological tests searching for IgG and IgM antibodies against Schistosoma spp. and results of 3 different PCR approaches searching species-overarching for Schistosoma spp. in general, and species-specific for $S$. haematobium and S. mansoni in 6 different locations at Madagascar.

\begin{tabular}{|c|c|c|c|c|c|c|c|c|}
\hline \multirow[b]{2}{*}{ Altitude } & \multirow[b]{2}{*}{$\mathrm{N}$} & \multicolumn{2}{|c|}{$\begin{array}{l}\text { Immunofluorescence } \\
\text { Assays, \% Positives * }\end{array}$} & \multicolumn{2}{|c|}{$\begin{array}{l}\text { ELISA, \% } \\
\text { Positives * }\end{array}$} & \multicolumn{3}{|c|}{ PCRs, \% Positives } \\
\hline & & $\operatorname{IgM}$ & $\operatorname{IgG}$ & $\operatorname{IgM}$ & $\operatorname{IgG}$ & $\begin{array}{l}\text { Schisto-soma } \\
\text { spp. }^{1}\end{array}$ & S. haematobium ${ }^{2}$ & S. mansoni $^{3}$ \\
\hline Littoral & 187 & $37.4 \%$ & $48.7 \%$ & $29.4 \%$ & $37.4 \%$ & $7.5 \%$ & 0 & $32.6 \%$ \\
\hline Littoral & 231 & $12.6 \%$ & $8.2 \%$ & $19.9 \%$ & $10.8 \%$ & 0 & 0 & $24.2 \%$ \\
\hline $466 \mathrm{~m}$ & 174 & $29.9 \%$ & $30.5 \%$ & $42.5 \%$ & $37.4 \%$ & $5.2 \%$ & 0 & $41.4 \%$ \\
\hline $920 \mathrm{~m}$ & 166 & $27.7 \%$ & $24.7 \%$ & $21.1 \%$ & $38.6 \%$ & $5.4 \%$ & 0 & $36.7 \%$ \\
\hline $860 \mathrm{~m}$ & 202 & $37.1 \%$ & $51.0 \%$ & $32.2 \%$ & $54.0 \%$ & $1.5 \%$ & 0 & $50.0 \%$ \\
\hline $1280 \mathrm{~m}$ & 194 & $29.4 \%$ & $63.4 \%$ & $29.4 \%$ & $71.1 \%$ & $14.4 \%$ & 0 & $69.1 \%$ \\
\hline All sites & 1154 & $28.5 \%$ & $37.3 \%$ & $28.8 \%$ & $40.8 \%$ & $5.5 \%$ & - & $42.0 \%$ \\
\hline $\begin{array}{c}\text { Point biserial } \\
\text { correlationcoefficient } \\
(p \text {-value })\end{array}$ & 1154 & $\begin{array}{c}0.0672 \\
(0.0224)\end{array}$ & $\begin{array}{c}0.2360 \\
(0.0001)\end{array}$ & $\begin{array}{c}0.0270 \\
(0.3595)\end{array}$ & $\begin{array}{c}0.3330 \\
(0.0001)\end{array}$ & $\begin{array}{c}0.1183 \\
(0.0001)\end{array}$ & & $\begin{array}{c}0.2614 \\
(0.0001)\end{array}$ \\
\hline
\end{tabular}

* Serological marginals in line the manufacturer's instructions were not counted as positives. ${ }^{1}$ Species-overarching PCR for Schistosoma spp. targeting the ITS-2 region of African Schistosoma spp. ${ }^{2}$ S. haematobium PCR targeting the highly repetitive Dra1 region of S. haematobium complex. ${ }^{3}$ S. mansoni PCR targeting the highly repetitive Sm1-7 region of S. mansoni complex. 


\subsection{Descriptive Comparison of the Test Results Applying Different Assays}

When comparing the test results of the serological methods (immunofluorescence vs. ELISA), $15.7 \%$ and $17.8 \%$ of the test comparisons based on positive or negative results (excluding borderline) according to the manufacturer's instructions were discordant (one test negative and the other positive). Cohens-Kappa values (Landis and Koch, 1977 [43]) were between $55 \%$ and $70 \%$ (Table 2 ).

Table 2. Comparison of test results between serological methods for the detection of schistosomiasis (immunofluorescence assay vs. ELISA, $n=1154)$.

\begin{tabular}{|c|c|c|c|c|c|c|c|}
\hline & & $\%$ Positive & $\begin{array}{l}\% \text { Concordant } \\
\text { Positive }\end{array}$ & $\begin{array}{l}\% \text { Concordant } \\
\text { Negative }\end{array}$ & $\%$ Discordant & Kappa (SE) & $\begin{array}{c}\text { Kappa } \\
\text { Interpretation }\end{array}$ \\
\hline IF IgG & \multirow{2}{*}{ Positive } & $37.3 \%$ & \multirow{2}{*}{$31.2 \%$} & \multirow{2}{*}{$53.1 \%$} & \multirow{2}{*}{$15.7 \%$} & \multirow{2}{*}{$67.1 \%(2.9 \%)$} & \multirow{2}{*}{ Substantial } \\
\hline ELISA IgG & & $40.8 \%$ & & & & & \\
\hline IF IgG & \multirow{2}{*}{$\begin{array}{c}\text { Positive and } \\
\text { borderline }\end{array}$} & $44.5 \%$ & \multirow{2}{*}{$38.0 \%$} & \multirow{2}{*}{$47.0 \%$} & \multirow{2}{*}{$15.1 \%$} & \multirow{2}{*}{$69.6 \%(2.9 \%)$} & \multirow{2}{*}{ Substantial } \\
\hline ELISA IgG & & $46.5 \%$ & & & & & \\
\hline IF IgM & \multirow{2}{*}{ Positive } & $28.5 \%$ & \multirow[t]{2}{*}{$19.8 \%$} & \multirow[t]{2}{*}{$62.5 \%$} & \multirow[t]{2}{*}{$17.8 \%$} & \multirow[t]{2}{*}{$56.5 \%(2.9 \%)$} & \multirow[t]{2}{*}{ Moderate } \\
\hline ELISA IgM & & $28.8 \%$ & & & & & \\
\hline IF IgM & \multirow{2}{*}{$\begin{array}{c}\text { Positive and } \\
\text { borderline }\end{array}$} & $36.1 \%$ & \multirow{2}{*}{$24.4 \%$} & \multirow{2}{*}{$55.2 \%$} & \multirow{2}{*}{$20.4 \%$} & \multirow[t]{2}{*}{$55.1 \%(2.9 \%)$} & \multirow{2}{*}{ Moderate } \\
\hline ELISA IgM & & $33.2 \%$ & & & & & \\
\hline
\end{tabular}

S.E. $=$ standard error.

Although serological examinations and PCR are entirely different diagnostic methods, at least outside high-endemic areas, one may want to compare IgM-serology and PCR as both methods may be seen as indicators for an acute schistosomiasis infection requiring praziquantel treatment. We therefore also compared serological methods looking for IgMs with PCRs. As none of the S. haematobium-specific PCRs emerged positive, it was excluded from this analysis. The overall poor inter-rater reliability measures between the different methods that could be seen as indicators for acute schistosomiasis infections is quite sobering (Table 3).

Table 3. Comparison of test results between serological methods for the detection of IgM antibodies and PCR methods (immunofluorescence assay vs. ELISA, $n=1154$ ).

\begin{tabular}{|c|c|c|c|c|c|c|}
\hline & $\%$ Positive & $\begin{array}{c}\% \\
\text { Concordantly } \\
\text { Positive }\end{array}$ & $\begin{array}{c}\% \\
\text { Concordantly } \\
\text { Negative }\end{array}$ & $\%$ Discordant & Kappa (SE) & $\begin{array}{c}\text { Kappa } \\
\text { Interpretation }\end{array}$ \\
\hline IF $\operatorname{Ig} M *$ & $28.5 \%$ & \multirow{2}{*}{$19.8 \%$} & \multirow{2}{*}{$62.5 \%$} & \multirow{2}{*}{$17.8 \%$} & \multirow{2}{*}{$56.5 \%(2.9 \%)$} & \multirow{2}{*}{ Moderate } \\
\hline ELISA IgM* & $28.8 \%$ & & & & & \\
\hline S. mansoni $\mathrm{PCR}^{2}$ & $42.3 \%$ & \multirow{2}{*}{$4.9 \%$} & \multirow{2}{*}{$57.5 \%$} & \multirow{2}{*}{$37.6 \%$} & \multirow{2}{*}{$12.3 \%(1.5 \%)$} & \multirow{2}{*}{ Slight } \\
\hline Schistosoma spp. PCR ${ }^{1}$ & $5.5 \%$ & & & & & \\
\hline IF IgM * & $28.5 \%$ & \multirow{2}{*}{$15.9 \%$} & \multirow{2}{*}{$45.3 \%$} & \multirow{2}{*}{$38.8 \%$} & \multirow{2}{*}{$16.6 \%(2.8 \%)$} & \multirow{2}{*}{ Slight } \\
\hline S. mansoni $\mathrm{PCR}^{2}$ & $42.3 \%$ & & & & & \\
\hline IF IgM * & $28.5 \%$ & \multirow{2}{*}{$2.5 \%$} & \multirow{2}{*}{$68.5 \%$} & \multirow{2}{*}{$28.9 \%$} & \multirow{2}{*}{$6.2 \%(2.0 \%)$} & \multirow{2}{*}{ Slight } \\
\hline Schistosoma spp. PCR ${ }^{1}$ & $5.5 \%$ & & & & & \\
\hline ELISA IgM * & $28.8 \%$ & \multirow{2}{*}{$13.3 \%$} & \multirow{2}{*}{$42.5 \%$} & \multirow{2}{*}{$44.3 \%$} & \multirow{2}{*}{$5.0 \%(2.8 \%)$} & \multirow{2}{*}{ Slight } \\
\hline S. mansoni $\mathrm{PCR}^{2}$ & $42.3 \%$ & & & & & \\
\hline ELISA IgM * & $28.8 \%$ & \multirow{2}{*}{$0.9 \%$} & \multirow{2}{*}{$66.6 \%$} & \multirow{2}{*}{$32.5 \%$} & \multirow{2}{*}{$-4.5 \%(2.0 \%)$} & \multirow{2}{*}{ Poor } \\
\hline Schistosoma spp. PCR ${ }^{1}$ & $5.5 \%$ & & & & & \\
\hline
\end{tabular}

S.E. $=$ standard error. ${ }^{*}$ Borderlines were not included as positives in the analysis. ${ }^{1}$ Species-overarching PCR for Schistosoma spp. targeting the ITS-2 region of African Schistosoma spp. ${ }^{2}$ S. mansoni PCR targeting the highly repetitive Sm1-7 region of S. mansoni complex. 
For the concordantly positive PCRs, we compared the Ct-values (Figure 2). As expected, a tendency for lower $\mathrm{Ct}$ values was seen with the more sensitive $\mathrm{S}$. mansoni complexspecific PCR approach, but with widely overlapping confidence intervals.

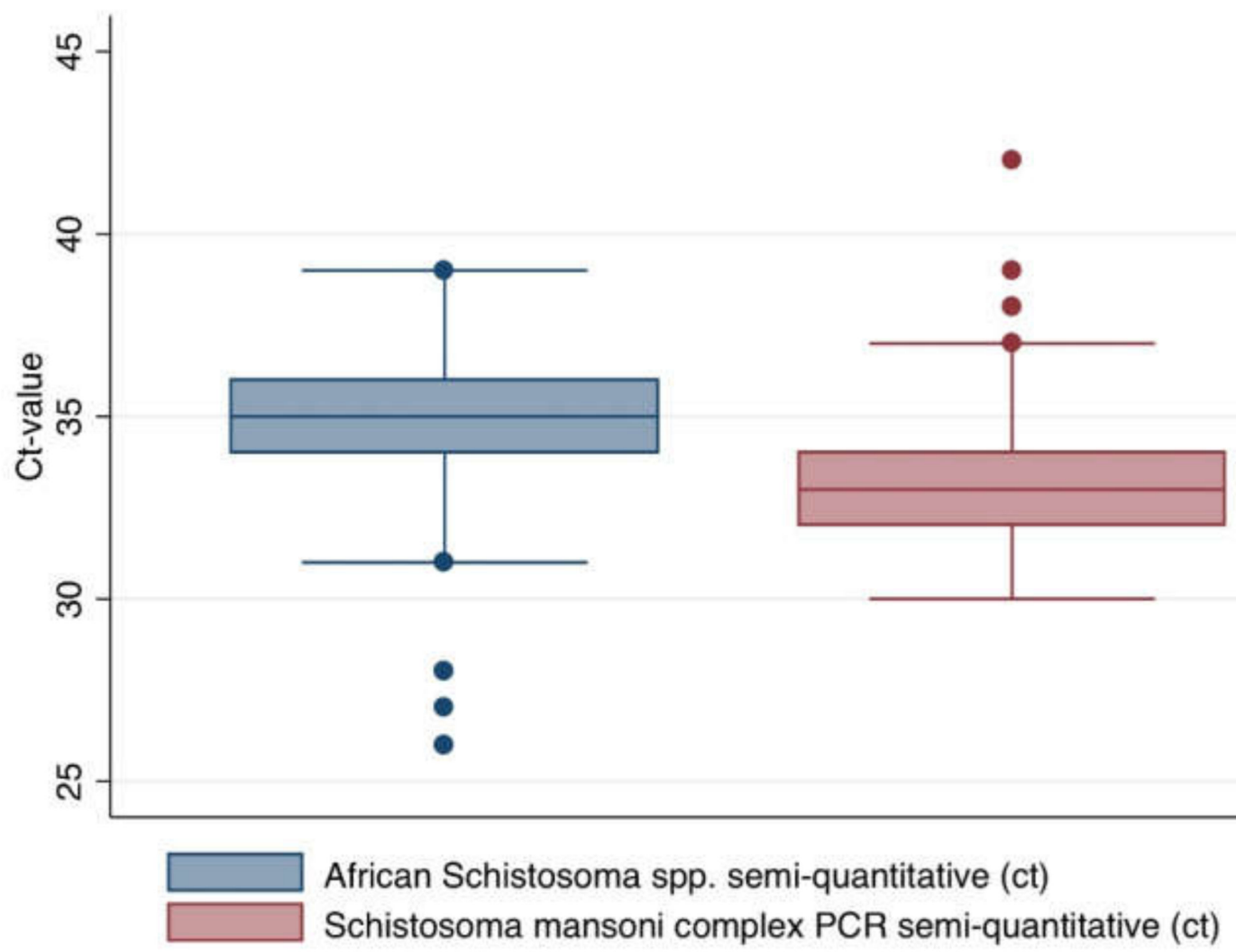

Figure 2. Comparison of cycle threshold values for the species-overarching PCR for Schistosoma spp. and the S. mansonispecific PCR for all concordantly positive results.

\subsection{Latent Class Assessment Based Calculation of the Test Characteristics and the Resulting Diagnostic-Accuracy Adjusted Overall Prevalence}

Applying latent class analysis on serological and PCR assays, both serological approaches for anti-Schistosoma-IgM scored with sensitivity $<50 \%$ and specificity $<90 \%$. Thereby, immunofluorescence was slightly more reliable than the ELISA approach. Focusing on IgG-antibodies, sensitivity of both approaches was in a similar range $>85 \%$, with specificity of ELISA $>90 \%$ and of immunofluorescence even $>95 \%$. Focusing on PCR, ITS-2-based genus specific PCR suggested low sensitivity $<15 \%$ but close-to perfect specificity. In comparison, S. mansoni complex-specific PCR with the multi-copy target Sm1-7 showed considerably better sensitivity of $74 \%$, but with reduced specificity close to $80 \%$. Considering those test-specific features, a diagnostic accuracy adjusted overall prevalence of $40.4 \%$ in the assessed population was calculated. Details are provided in Table 4.

\subsection{Estimation of Potential Influence of Cross-Reacting Anti-Malarial Antibodies}

Making effects of cross-reacting anti-malarial antibodies unlikely, the phi coefficient for the serological assessments for antimalarial antibodies without further differentiation of antibody-subpopulations as previously described [29] and for the presently assessed anti-Schistosoma-antibodies scored in a similar range as the phi coefficient for malaria PCR [29] and for schistosomiasis PCR. Especially for the PCR approaches, cross-reactivity is unlikely for methodological reasons. Due to the weak association between altitude 
and schistosomiasis prevalence, individual phi-values for different study sites were not calculated. Details are provided in Table 5.

Table 4. Test characteristics as calculated based on latent class assessment and the resulting diagnostic accuracy adjusted overall prevalence rate.

\begin{tabular}{|c|c|c|c|c|c|c|c|}
\hline \multirow[b]{2}{*}{$N=1154$} & \multicolumn{2}{|c|}{ Immunofluorescence Assays } & \multicolumn{2}{|c|}{ ELISA of } & \multicolumn{3}{|c|}{ PCR } \\
\hline & $\operatorname{IgM}$ & $\operatorname{IgG}$ & $\operatorname{IgM}$ & $\operatorname{IgG}$ & Schistosoma spp. & S. haematobium & S. mansoni \\
\hline $\begin{array}{l}\text { Sensitivity } \\
(0.95 \mathrm{CI})\end{array}$ & $\begin{array}{c}0.4913 \\
(0.4438 \\
0.5391)\end{array}$ & $\begin{array}{c}0.8696 \\
(0.8142, \\
0.9103)\end{array}$ & $\begin{array}{c}0.3829 \\
(0.3377, \\
0.4302)\end{array}$ & $\begin{array}{c}0.8759 \\
(0.8282, \\
0.9118)\end{array}$ & $\begin{array}{c}0.1349 \\
(0.1061,0.1702)\end{array}$ & - & $\begin{array}{c}0.7406 \\
(0.6929 \\
0.7832)\end{array}$ \\
\hline $\begin{array}{l}\text { Specificity } \\
(0.95 \mathrm{CI})\end{array}$ & $\begin{array}{c}0.8549 \\
(0.8221 \\
0.8825)\end{array}$ & $\begin{array}{c}0.9647 \\
(0.934 \\
0.9811)\end{array}$ & $\begin{array}{c}0.7769 \\
(0.7418 \\
0.8085)\end{array}$ & $\begin{array}{c}0.9093 \\
(0.8753 \\
0.9347)\end{array}$ & $\begin{array}{c}0.9999 \\
(0,1)\end{array}$ & - & $\begin{array}{c}0.7971 \\
(0.7618 \\
0.8284)\end{array}$ \\
\hline $\begin{array}{c}\text { Prevalence } \\
\text { rate }(0.95 \mathrm{CI})\end{array}$ & \multicolumn{7}{|c|}{$40.4 \%(36.8 \%, 44.1 \%)$} \\
\hline
\end{tabular}

Table 5. Phi coefficients to assess potential cross-reactions between anti-malarial and anti-Schistosoma-antibodies as well as comparison with malaria and schistosomiasis PCR. Data for the malaria assessments were taken from a previous publication [29].

\begin{tabular}{cccccccc}
\hline & \multicolumn{2}{c}{$\begin{array}{c}\text { Immunofluorescence } \\
\text { Assays }\end{array}$} & \multicolumn{2}{c}{ ELISA } & & PCR \\
\hline $\mathrm{N}=1154$ & $\operatorname{IgM}$ & $\operatorname{IgG}$ & $\operatorname{IgM}$ & $\operatorname{IgG}$ & Schistosoma spp. & S. haematobium & S. mansoni \\
\hline Phi coefficient * & 0.0372 & 0.1150 & 0.0297 & 0.1417 & 0.1231 & - & 0.1006 \\
\hline
\end{tabular}

* for concordance between malaria serology and Schistosoma spp. diagnostics.

\section{Discussion}

The primary objective of the study was the assessment of the prevalence of previous or active schistosomiasis by serology [36], as well as likely active infection [37] by real-time PCR in Madagascan pregnant women. Of note, blood PCR for schistosomiasis can stay positive for a limited period of time after successful therapy as well [37]. The diagnostic accuracy adjusted prevalence estimation [44] suggested an overall prevalence of $40.4 \%$. This high percentage is, interestingly, even lower than in previous reports from other assessments in Madagascar targeting other subpopulations [1,2,4,5]. The reasons for the surprisingly low IgG prevalence compared to the PCR results remain unresolved, although a considerable proportion of new infections, in which seroconversion had not occurred yet, cannot be completely excluded. Another likely reason is the previously described phenomenon of reduced antibody responses against Schistosoma spp. in pregnancy as described in 2009 [45]. Of note, only moderately differing percentages were recorded at different assessed study sites and both serology and PCR pointed in a similar direction regarding the proportion of positive samples. Focusing on the altitude of the different study sites, no strong correlations have been seen in spite of P-values suggesting significance for a weak association. At one side at sea level, interestingly, seropositivity rate was particularly low with relatively high IgM prevalence compared to IgG as well as comparably high rates of positive PCR. This composition of results could indicate active transmission of infections. As suggested by species complex-specific PCR, S. mansoni was the only detectable pathogen, while serological assessment did not allow discrimination on species level. The lacking detection of S. haematobium-specific DNA is in line with previous reports [10-14], suggesting endemicity of S. haematobium in the Northern and Western regions of Madagascar. Those regions were not in the focus of the presented study.

Although praziquantel therapy of schistosomiasis during pregnancy is recommended by the World Health Organization (WHO) [46], nationwide screening and screening-based therapy for pregnant women is so far not established in resource-poor Madagascar. At 
present, investigations on the suitability of test-and-treat strategies for the reduction of the burden of schistosomiasis in pregnant Madagascan women are underway [47].

Generally, species-specific PCR for highly repetitive multi-copy targets like Sm1-7 [33] or Dra1 [34] is considered more sensitive than genus-specific PCR targeting less repetitive genetic elements like ITS-2 [31] and is thus usually applied for PCR from blood [33,35]. When comparing Ct-values obtained by species-specific and genus-specific PCRs, widely overlapping confidence intervals counteracted a tendency for the expected lower Ctvalues in case of species complex-specific PCR with specificity for a multi-copy target. Further, latent class analysis suggested better specificity of the genus-specific ITS-2 PCR compared with the more sensitive Sm1-7-based protocols. Accordingly, while speciesspecific PCR proofed to be more sensitive for Schistosoma DNA in blood, positive results obtained by the ITS-2-based genus-specific PCR provided a higher degree of reliability in the assessed samples from a tropical high endemicity setting. Compared to a recent assessment of S. mansoni-specific Sm1-7 real-time PCR with travelers and migrants [48], both sensitivity and specificity estimations for this PCR assay in the present assessment in the Madagascan high endemicity setting suggested slightly worse diagnostic accuracy, although there is considerable overlapping of the confidence intervals (evaluation data with travelers and migrants freely accessible under [48]). This finding confirms that validation of diagnostic assays is crucial [49] and needs to be independently performed for different geographic settings.

Regarding serology, both sensitivity and specificity of IgG-based immunofluorescence and ELISA outperformed the IgM-specific assays as suggested by LCA analysis. For both immunoglobulin subclasses, the immunofluorescence assay was slightly superior as suggested by latent class analysis. Whether or not such differences justify the preference of the more laborious immunofluorescence approach over automatable ELISA in the diagnostic routine remains an individual decision. Observed poor to slight correlation of positive PCR and positive IgM results discourage the use of IgM as an activity marker of the infection in highly endemic settings like in Madagascar. The result can be explained by the facts that active infection does not necessarily mean new infection, and that reinfections may readily occur in high endemicity settings [36] like in Madagascar.

A previous assessment of the same samples for Plasmodium spp. [29] allowed the analysis of potential interfering effects between schistosomiasis serology and malaria serology as suggested previously [39-41]. Interestingly, the observed phi coefficient for concordance between malaria serology and Schistosoma spp.-specific serology was negligibly low and there was no big difference between the phi coefficients for serology and PCR. Accordingly, it can be concluded that the applied serological approaches may be relatively robust regarding potential interfering influence of malaria-specific antibodies.

The study has a number of limitations. First of all, its retrospective nature based on yet available residual sample materials did not allow the inclusion of diagnostic approaches other than PCR and serology from blood. Other approaches like antigen testing from urine [32], PCR from stool, urine, sperm, or bioptically acquired materials as well as traditional microscopic assessments [4] could not be added to define a more reliable composite reference standard. Secondly, the samples were more than 10 years old when the assessments were performed. Although the residual materials had been adequately stored at $-80^{\circ} \mathrm{C}$ prior to the assessments, effects of long-term storage on the test results cannot be completely excluded. Thirdly, the Sm1-7-based and the Dra1-based PCR approaches as well as the serological immunofluorescence assays had been developed and evaluated primarily for serum, not for EDTA plasma. Only the ELISA had been previously validated by the manufacturer for plasma. Accordingly, sample matrix-specific effects may have influenced the results as well. All those pre-analytic conditions cannot be changed but have to be considered while interpreting the study results. Further, prospective assessments with fresh sample materials are advisable. Fourthly, the combined presentation of epidemiological prevalence assessments and test evaluation results may be dissatisfying for readers just looking for the one or the other. However, test accuracy can vary at different geographic 
regions as discussed for the blood PCR above depending on the endemicity of target microorganisms and potentially cross-reacting non-target microorganisms [43]. In turn, test accuracy can influence study results like prevalence estimations [49], so it makes sense to evaluate diagnostic accuracy at the study site.

\section{Materials and Methods}

\subsection{Study Design and Sample Materials}

A cross-sectional study was conducted based on residual EDTA plasma samples $[25-27,30]$ and nucleic acid extractions from urea-stabilized EDTA blood samples [28,29] from 1244 pregnant Madagascan women obtained between April and July 2010 in 6 different locations in Madagascar, 2 coastal and 4 in the highlands. The samples had been taken at the time of routine check-ups during pregnancy. Thereby, however, the sample acquisition was study-associated.

At the time of sample acquisition, neither routine screening nor associated treatment of schistosomiasis had been an element of routine check-ups for Madagascan pregnant women.

All residual EDTA plasma samples and nucleic acid extractions had been stored frozen at $-80{ }^{\circ} \mathrm{C}$ prior to the assessments.

\subsection{PCR Protocols}

In total, three real time PCR assays were applied with the residual nucleic acid extractions from urea-pretreated blood; (i) a Schistosoma-ssp.-overarching PCR targeting the ITS-2 region for Schistosoma spp., thus detecting S. mansoni, S. haematobium, and S. intercalatum [31], (ii) a PCR specific for the $S$. mansoni complex targeting the highly repetitive Sm1-7 region of S. mansoni [33,50]; and (iii) a PCR targeting the highly repetitive Dra1 region of S. haematobium complex [34]. PCRs were run on RotorGene Q (Qiagen, Hilden, Germany) or MIC (Bio Molecular Systems, Upper Coomera, Australia) cyclers as previously described $[31,33,34,48]$. The Sm1-7 assay and the Dra1 assay were run in a one-tube duplex approach as detailed elsewhere [47]. Internal control was based upon the amplification of Phocid herpes virus DNA [51].

\subsection{Serology}

Serological assessments were performed using commercial anti-Schistosoma IgM- and IgG ELISA and immunofluorescence assays (EUROIMMUN Medizinische Labordiagnostika AG, Lübeck, Germany). While optical density values were measured for the ELISA assessments, positive slides in immunofluorescence at 1:10 dilution were additionally assessed applying the titers 1:100 and 1:1000 for quantification purposes. Previous data on Plasmodium spp. detections within the samples [29] were used to evaluate potential cross-reaction by calculating the phi coefficient.

\subsection{Inclusion Or Exclusion Criteria}

All available residual samples were assessed. Insufficient sample material for all assessments or lacking clinical information were no exclusion criteria.

\subsection{Statistical Assessment}

For each diagnostic method, we calculated the prevalence of positives and then compared the agreement between the tests. Association with the altitude of the assessed study sites was analyzed calculating the point biserial correlation coefficient. The proportion of concordant positives and discordant results between the serological methods and between PCR-methods and IgM-antibody detections methods were determined. Agreement (kappa) between the tests was calculated and categorized based on the category's poor (below 0.00 ), slight (0.00-0.20), fair (0.21-0.40), moderate (0.41-0.60), substantial (0.61-0.80), and almost perfect (0.81-1.00) as suggested [43]. In case of concordantly positive results between genusspecific PCR and species-specific PCR, cycle threshold values were comparatively assessed. Latent class analysis (LCA) $[44,52]$ was applied to calculate sensitivity and specificity of 
the serological and molecular tests. Additionally, LCA-based calculation of diagnostic accuracy-adjusted overall prevalence of schistosomiasis within the investigated population was performed. Prior to those calculations, relevant association between malaria and schistosomiasis positivity was excluded by calculating the phi-coefficient. All analyses were done applying Stata version 14 (College Station, TX, USA).

The population prevalence was estimated based on the positives within the assessed samples conducting LCA and was provided with a 95\% confidence interval.

\subsection{Ethical Clearance}

Madagascan ethical clearance for the epidemiological assessment was provided by the “Comité d'Ethique de la Recherche Biomédicale auprès du Ministère de la Santé Publique de Madagascar" (No 77 MSANP/SG/-AGMED/CNPV/CERBM) as an extension of the ethical approval of the original sample collection (Autorisation 051-CE/MINSAN du 02 Novembre 2009). In addition, ethical clearance for blinded use of residual materials for test comparison and evaluation purposes was granted by the ethics committee of the Medical Association of Hamburg, Germany (registration number WF-011/19) in line with German national laws.

\section{Conclusions}

In spite of the abovementioned limitations, this study indicated a high prevalence of schistosomiasis among pregnant women in Madagascar as confirmed by blood PCR and serology [36,37] with considerable disease activity as confirmed by blood PCR [37]. Further, the study confirmed high sensitivity of Sm1-7-based blood PCR for S. mansoni complex [33]. However, less sensitive approaches like ITS-2-based PCR [31,53] may be useful for surveillance purposes in high endemicity settings as well, if optimum specificity is desired. Only slight to moderate superiority of comparatively laborious immunofluorescence-based schistosomiasis serology over automatable ELISA suggests ELISA-based surveillance as an option worth considering, in particular, if diagnostic accuracy adjusted prevalence estimation [42] is applied to calculate the true prevalence.

As a more indirect conclusion, the study showed that historic sample materials can be valuable by allowing the assessment of diagnostic assays targeting neglected tropical diseases. Insofar, the study also encourages microbiological biobanking [54,55], a strategy which has already been suggested as promising for the development of diagnostic tools for sleeping sickness [56].

Author Contributions: Conceptualization, H.F. and N.G.S.; methodology, T.H., I.C., A.H., O.M.-A., N.G.S.; software, A.H., N.G.S.; validation, A.H., N.G.S. and H.F.; formal analysis, A.H., N.G.S., T.H., I.C., H.F.; investigation, T.H., I.C.; resources, R.R., N.R., O.M.-A., A.P., H.F.; data curation, T.H., I.C., A.H., N.G.S.; writing-original draft preparation, H.F., N.G.S., A.H.; writing-review and editing, T.H., I.C., R.R., M.G., O.M.-A., N.R., A.P., A.H., H.F., N.G.S.; visualization, N.G.S.; supervision, H.F., N.G.S.; project administration, H.F., N.G.S.; funding acquisition, A.P., H.F. All authors have read and agreed to the published version of the manuscript.

Funding: The study was funded by grant 36K2-S-45 1922 “Evaluation and optimization of molecular diagnostic tests for tropical parasitic diseases for surveillance and risk assessment purposes in tropical deployment settings-a German-French cooperation project between the German Armed Forces Hospital Hamburg and the Military Hospital Laveran, Marseille" of the German Ministry of Defense (MoD) awarded to Hagen Frickmann. Open access publishing was supported by the open access publishing fund of the University Medicine Rostock.

Institutional Review Board Statement: The study was conducted according to the guidelines of the Declaration of Helsinki. Madagascan ethical clearance for the epidemiological assessment was provided by the "Comité d'Ethique de la Recherche Biomédicale auprès du Ministère de la Santé Publique de Madagascar" (No 77 MSANP/SG/-AGMED/CNPV/CERBM) as an extension of the ethical approval of the original sample collection (Autorisation 051-CE/MINSAN du 02 Novembre 2009). In addition, ethical clearance for blinded use of residual materials for test comparison and 
evaluation purposes was granted by the ethics committee of the Medical Association of Hamburg, Germany (registration number WF-011/19) in line with German national laws.

Informed Consent Statement: Informed consent was obtained from all subjects involved in the study.

Data Availability Statement: All relevant data are provided in the manuscript. Raw data can be made available on reasonable request.

Acknowledgments: Annett Michel, and Simone Priesnitz are gratefully acknowledged for excellent technical assistance.

Conflicts of Interest: The funders had no role in the design of the study; in the collection, analyses, or interpretation of data; in the writing of the manuscript, or in the decision to publish the results.

\section{Appendix A. Distribution of the Excluded Samples due to Insufficient Sample Volumes on the Different Study Sides by Altitude}

\begin{tabular}{ccc}
\hline Altitude & $\begin{array}{c}\text { Total Number of Collected } \\
\text { Samples (\%) }\end{array}$ & $\begin{array}{c}\text { Excluded Samples due to } \\
\text { Insufficient Sample Volumes (\%) }\end{array}$ \\
\hline Littoral & $195(100.0)$ & $8(4.1)$ \\
Littoral & $251(100.0)$ & $20(8.0)$ \\
$466 \mathrm{~m}$ & $197(100.0)$ & $23(11.7)$ \\
$860 \mathrm{~m}$ & $203(100.0)$ & $1(0.5)$ \\
$920 \mathrm{~m}$ & $198(100.0)$ & $32(16.2)$ \\
$1280 \mathrm{~m}$ & $200(100.0)$ & $6(3.0)$ \\
\hline
\end{tabular}

\section{References}

1. Rasoamanamihaja, C.F.; Rahetilahy, A.M.; Ranjatoarivony, B.; Dhanani, N.; Andriamaro, L.; Andrianarisoa, S.H.; Jourdan, P.M. Baseline prevalence and intensity of schistosomiasis at sentinel sites in Madagascar: Informing a national control strategy. Parasit. Vectors 2016, 9, 50. [CrossRef]

2. Russell, H.J.; Penney, J.M.S.; Linder, C.; Joekes, E.C.; Bustinduy, A.L.; Stothard, J.R.; Rakotomampianina, D.A.L.; Andriamasy, E.H.; Mahary, L.R.; Ranjanoro, E.P.; et al. A cross-sectional study of periportal fibrosis and Schistosoma mansoni infection among school-aged children in a hard-to-reach area of Madagascar. Trans. R. Soc. Trop. Med. Hyg. 2020, 114, 315-322. [CrossRef] [PubMed]

3. Boisier, P.; Serieye, J.; Ravaoalimalala, V.E.; Roux, J.; Esterre, P. Ultrasonographical assessment of morbidity in schistosomiasis mansoni in Madagascar: A community-based study in a rural population. Trans. R. Soc. Trop. Med. Hyg. 1995, 89, $208-212$. [CrossRef]

4. Schwarz, N.G.; Rakotozandrindrainy, R.; Heriniaina, J.N.; Randriamampionona, N.; Hahn, A.; Hogan, B.; Frickmann, H.; Dekker, D.; Poppert, S.; Razafindrabe, T.; et al. Schistosoma mansoni in schoolchildren in a Madagascan highland school assessed by PCR and sedimentation microscopy and Bayesian estimation of sensitivities and specificities. Acta Trop. 2014, 134, 89-94. [CrossRef] [PubMed]

5. Spencer, S.A.; Penney, J.M.S.J.; Russell, H.J.; Howe, A.P.; Linder, C.; Rakotomampianina, A.L.D.; Nandimbiniaina, A.M.; Squire, S.B.; Stothard, J.R.; Bustinduy, A.L.; et al. High burden of Schistosoma mansoni infection in school-aged children in Marolambo District, Madagascar. Parasit. Vectors 2017, 10, 307. [CrossRef] [PubMed]

6. Pfluger, W. Ecological studies in Madagascar of Biomphalaria pfeifferi, intermediate host of Schistosoma mansoni. 2. Biology and dynamics in the non-endemic area of Antananarivo. Arch. Inst. Pasteur Madagascar. 1978, 46, 241-269. [PubMed]

7. Stothard, J.R.; Brémond, P.; Andriamaro, L.; Sellin, B.; Sellin, E.; Rollinson, D. Bulinus species on Madagascar: Molecular evolution, genetic markers and compatibility with Schistosoma haematobium. Parasitology 2001, 123, S261-S275. [CrossRef]

8. Charbonnel, N.; Angers, B.; Rasatavonjizay, R.; Bremond, P.; Debain, C.; Jarne, P. The influence of mating system, demography, parasites and colonization on the population structure of Biomphalaria pfeifferi in Madagascar. Mol. Ecol. 2002, 11, $2213-2228$. [CrossRef]

9. Sato, M.O.; Rafalimanantsoa, A.; Ramarokoto, C.; Rahetilahy, A.M.; Ravoniarimbinina, P.; Kawai, S.; Minamoto, T.; Sato, M.; Kirinoki, M.; Rasolofo, V.; et al. Usefulness of environmental DNA for detecting Schistosoma mansoni occurrence sites in Madagascar. Int. J. Infect. Dis. 2018, 76, 130-136. [CrossRef]

10. Serieye, J.; Boisier, P.; Ravaoalimalala, V.E.; Ramarokoto, C.E.; Leutscher, P.; Esterre, P.; Roux, J. Schistosoma haematobium infection in western Madagascar: Morbidity determined by ultrasonography. Trans. R. Soc. Trop. Med. Hyg. 1996, 90, 398-401. [CrossRef]

11. Leutscher, P.; Raharisolo, C.; Pecarrere, J.L.; Ravaoalimalala, V.E.; Serieye, J.; Rasendramino, M.; Vennervald, B.; Feldmeier, H.; Esterre, P. Schistosoma haematobium induced lesions in the female genital tract in a village in Madagascar. Acta Trop. 1997, 66, 27-33. [CrossRef] 
12. Leutscher, P.; Ramarokoto, C.E.; Reimert, C.; Feldmeier, H.; Esterre, P.; Vennervald, B.J. Community-based study of genital schistosomiasis in men from Madagascar. Lancet 2000, 355, 117-118. [CrossRef]

13. Leutscher, P.D.; Høst, E.; Reimert, C.M. Semen quality in Schistosoma haematobium infected men in Madagascar. Acta Trop. 2009, 109, 41-44. [CrossRef]

14. Ramarakoto, C.E.; Leutscher, P.D.; Van Dam, G.; Christensen, N.O. Ultrasonographical findings in the urogenital organs in women and men infected with Schistosoma haematobium in northern Madagascar. Trans. R. Soc. Trop. Med. Hyg. 2008, 102, 767-773. [CrossRef] [PubMed]

15. Randrianasolo, B.S.; Jourdan, P.M.; Ravoniarimbinina, P.; Ramarokoto, C.E.; Rakotomanana, F.; Ravaoalimalala, V.E.; Gundersen, S.G.; Feldmeier, H.; Vennervald, B.J.; Van Lieshout, L.; et al. Gynecological manifestations, histopathological findings, and schistosoma-specific polymerase chain reaction results among women with Schistosoma haematobium infection: A cross-sectional study in Madagascar. J. Infect. Dis. 2015, 212, 275-284. [CrossRef] [PubMed]

16. Laxman, V.V.; Adamson, B.; Mahmood, T. Recurrent ectopic pregnancy due to Schistosoma hematobium. J. Obstet. Gynaecol. 2008, 28, 461-462. [CrossRef] [PubMed]

17. Siegrist, D.; Siegrist-Obimpeh, P. Schistosoma haematobium infection in pregnancy. Acta Trop. 1992, 50, 317-321. [CrossRef]

18. Friedman, J.F.; Mital, P.; Kanzaria, H.K.; Olds, G.R.; Kurtis, J.D. Schistosomiasis and pregnancy. Trends Parasitol. 2007, 23, 159-164. [CrossRef] [PubMed]

19. Mombo-Ngoma, G.; Honkpehedji, J.; Basra, A.; Mackanga, J.R.; Zoleko, R.M.; Zinsou, J.; Agobe, J.C.; Lell, B.; Matsiegui, P.B.; Gonzales, R.; et al. Urogenital schistosomiasis during pregnancy is associated with low birth weight delivery: Analysis of a prospective cohort of pregnant women and their offspring in Gabon. Int. J. Parasitol. 2017, 47, 69-74. [CrossRef] [PubMed]

20. Ajanga, A.; Lwambo, N.J.; Blair, L.; Nyandindi, U.; Fenwick, A.; Brooker, S. Schistosoma mansoni in pregnancy and associations with anaemia in northwest Tanzania. Trans. R. Soc. Trop. Med. Hyg. 2006, 100, 59-63. [CrossRef] [PubMed]

21. Tweyongyere, R.; Naniima, P.; Mawa, P.A.; Jones, F.M.; Webb, E.L.; Cose, S.; Dunne, D.W.; Elliott, A.M. Effect of maternal Schistosoma mansoni infection and praziquantel treatment during pregnancy on Schistosoma mansoni infection and immune responsiveness among offspring at age five years. PLoS Negl. Trop. Dis. 2013, 7, e2501. [CrossRef]

22. Santos, P.d.A.; De Lorena, V.M.B.; Fernandes Éde, S.; Sales, I.R.; Nascimento, W.R.; De Miranda Gomes, Y.; Albuquerque, M.C.; Costa, V.M.; Souza, V.M. Gestation and breastfeeding in schistosomotic mothers differently modulate the immune response of adult offspring to postnatal Schistosoma mansoni infection. Mem. Inst. Oswaldo Cruz. 2016, 111, 83-92. [CrossRef] [PubMed]

23. Da Paz, V.R.F.; Sequeira, D.; Pyrrho, A. Infection by Schistosoma mansoni during pregnancy: Effects on offspring immunity. Life Sci. 2017, 185, 46-52. [CrossRef] [PubMed]

24. Lacorcia, M.; Prazeres da Costa, C.U. Maternal Schistosomiasis: Immunomodulatory Effects with Lasting Impact on Allergy and Vaccine Responses. Front. Immunol. 2018, 9, 2960. [CrossRef] [PubMed]

25. Schwarz, N.G.; Girmann, M.; Randriamampionona, N.; Bialonski, A.; Maus, D.; Krefis, A.C.; Njarasoa, C.; Rajanalison, J.F.; Ramandrisoa, H.D.; Randriarison, M.L.; et al. Seroprevalence of antibodies against Chikungunya, Dengue, and Rift Valley fever viruses after febrile illness outbreak, Madagascar. Emerg. Infect. Dis. 2012, 18, 1780-1786. [CrossRef]

26. Schwarz, N.G.; Mertens, E.; Winter, D.; Maiga-Ascofaré, O.; Dekker, D.; Jansen, S.; Tappe, D.; Randriamampionona, N.; May, J.; Rakotozandrindrainy, R.; et al. No serological evidence for Zika virus infection and low specificity for anti-Zika virus ELISA in malaria positive individuals among pregnant women from Madagascar in 2010. PLoS ONE 2017, 12, e0176708. [CrossRef] [PubMed]

27. Frickmann, H.; Schwarz, N.G.; Girmann, M.; Hagen, R.M.; Poppert, S.; Crusius, S.; Podbielski, A.; Heriniaina, J.N.; Razafindrabe, T.; Rakotondrainiarivelo, J.P.; et al. Serological survey of HIV and syphilis in pregnant women in Madagascar. Trop. Med. Int. Health. 2013, 18, 35-39. [CrossRef] [PubMed]

28. Garigliany, M.M.; Hagen, R.M.; Frickmann, H.; May, J.; Schwarz, N.G.; Perse, A.; Jöst, H.; Börstler, J.; Shahhosseini, N.; Desmecht, D.; et al. Cyclovirus CyCV-VN species distribution is not limited to Vietnam and extends to Africa. Sci. Rep. 2014, 4, 7552. [CrossRef] [PubMed]

29. Maïga-Ascofaré, O.; Rakotozandrindrainy, R.; Girmann, M.; Hahn, A.; Randriamampionona, N.; Poppert, S.; May, J.; Schwarz, N.G. Molecular epidemiology and seroprevalence in asymptomatic Plasmodium falciparum infections of Malagasy pregnant women in the highlands. Malar. J. 2015, 14, 188. [CrossRef]

30. Keller, C.; Krüger, A.; Schwarz, N.G.; Rakotozandrindrainy, R.; Rakotondrainiarivelo, J.P.; Razafindrabe, T.; Derschum, H.; Silaghi, C.; Pothmann, D.; Veit, A.; et al. High detection rate of Rickettsia africae in Amblyomma variegatum but low prevalence of anti-rickettsial antibodies in healthy pregnant women in Madagascar. Ticks Tick Borne Dis. 2016, 7, 60-65. [CrossRef] [PubMed]

31. Obeng, B.B.; Aryeetey, Y.A.; De Dood, C.J.; Amoah, A.S.; Larbi, I.A.; Deelder, A.M.; Yazdanbakhsh, M.; Hartgers, F.C.; Boakye, D.A.; Verweij, J.J.; et al. Application of a circulating-cathodic-antigen (CCA) strip test and real-time PCR, in comparison with microscopy, for the detection of Schistosoma haematobium in urine samples from Ghana. Ann. Trop. Med. Parasitol. 2008, 102, 625-633. [CrossRef] [PubMed]

32. Ochodo, E.A.; Gopalakrishna, G.; Spek, B.; Reitsma, J.B.; Van Lieshout, L.; Polman, K.; Lamberton, P.; Bossuyt, P.M.; Leeflang, M.M. Circulating antigen tests and urine reagent strips for diagnosis of active schistosomiasis in endemic areas. Cochrane Database Syst. Rev. 2015, 3, CD009579. [CrossRef] [PubMed]

33. Wichmann, D.; Panning, M.; Quack, T.; Kramme, S.; Burchard, G.D.; Grevelding, C.; Drosten, C. Diagnosing schistosomiasis by detection of cell-free parasite DNA in human plasma. PLoS Negl. Trop. Dis. 2009, 3, e422. [CrossRef] [PubMed] 
34. Cnops, L.; Soentjens, P.; Clerinx, J.; Van Esbroeck, M. A Schistosoma haematobium-specific real-time PCR for diagnosis of urogenital schistosomiasis in serum samples of international travelers and migrants. PLoS Negl. Trop. Dis. 2013, 7, e2413. [CrossRef] [PubMed]

35. Guegan, H.; Fillaux, J.; Charpentier, E.; Robert-Gangneux, F.; Chauvin, P.; Guemas, E.; Boissier, J.; Valentin, A.; Cassaing, S.; Gangneux, J.P.; et al. Real-time PCR for diagnosis of imported schistosomiasis. PLoS Negl. Trop. Dis. 2019, 13, e0007711. [CrossRef] [PubMed]

36. Hinz, R.; Schwarz, N.G.; Hahn, A.; Frickmann, H. Serological approaches for the diagnosis of schistosomiasis-A review. Mol. Cell. Probes 2017, 31, 2-21. [CrossRef]

37. Fuss, A.; Mazigo, H.D.; Mueller, A. Evaluation of serum-based real-time PCR to detect Schistosoma mansoni infection before and after treatment. Infect. Dis. Poverty. 2020, 9, 74. [CrossRef] [PubMed]

38. Fairlie-Clarke, K.J.; Lamb, T.J.; Langhorne, J.; Graham, A.L.; Allen, J.E. Antibody isotype analysis of malaria-nematode co-infection: Problems and solutions associated with cross-reactivity. BMC Immunol. 2010, 11, 6. [CrossRef]

39. Naus, C.W.; Jones, F.M.; Satti, M.Z.; Joseph, S.; Riley, E.M.; Kimani, G.; Mwatha, J.K.; Kariuki, C.H.; Ouma, J.H.; Kabatereine, N.B.; et al. Serological responses among individuals in areas where both schistosomiasis and malaria are endemic: Cross-reactivity between Schistosoma mansoni and Plasmodium falciparum. J. Infect. Dis. 2003, 187, 1272-1282. [CrossRef]

40. Pierrot, C.; Wilson, S.; Lallet, H.; Lafitte, S.; Jones, F.M.; Daher, W.; Capron, M.; Dunne, D.W.; Khalife, J. Identification of a novel antigen of Schistosoma mansoni shared with Plasmodium falciparum and evaluation of different cross-reactive antibody subclasses induced by human schistosomiasis and malaria. Infect. Immun. 2006, 74, 3347-3354. [CrossRef] [PubMed]

41. Helmby, H. Schistosomiasis and malaria: Another piece of the crossreactivity puzzle. Trends Parasitol. 2007, 23, 88-90. [CrossRef] [PubMed]

42. Rogan, W.J.; Gladen, B. Estimating prevalence from the results of a screening test. Am. J. Epidemiol. 1978, 107, 71-76. [CrossRef] [PubMed]

43. Landis, J.R.; Koch, G.G. The measurement of observer agreement of categorical data. Biometrics 1977, 33, 159-174. [CrossRef]

44. Hahn, A.; Podbielski, A.; Meyer, T.; Zautner, A.E.; Loderstädt, U.; Schwarz, N.G.; Krüger, A.; Cadar, D.; Frickmann, H. On detection thresholds-a review on diagnostic approaches in the infectious disease laboratory and the interpretation of their results. Acta Trop. 2020, 205, 105377. [CrossRef] [PubMed]

45. Tweyongyere, R.; Mawa, P.A.; Emojong, N.O.; Mpairwe, H.; Jones, F.M.; Duong, T.; Dunne, D.W.; Vennervald, B.J.; KatungukaRwakishaya, E.; Elliott, A.M. Effect of praziquantel treatment of Schistosoma mansoni during pregnancy on intensity of infection and antibody responses to schistosome antigens: Results of a randomised, placebo-controlled trial. BMC Infect. Dis. $2009,9,32$. [CrossRef]

46. Friedman, J.F.; Olveda, R.M.; Mirochnick, M.H.; Bustinduy, A.L.; Elliott, A.M. Praziquantel for the treatment of schistosomiasis during human pregnancy. Bull. World Health Organ. 2018, 96, 59-65. [CrossRef] [PubMed]

47. Hoekstra, P.T.; Schwarz, N.G.; Adegnika, A.A.; Andrianarivelo, M.R.; Corstjens, P.L.A.M.; Rakotoarivelo, R.A.; Rakotozandrindrainy, R.; Sicuri, E.; Kreidenweiss, A.; Van Dam, G.J. freeBILy consortium. Fast and reliable easy-to-use diagnostics for eliminating bilharzia in young children and mothers: An introduction to the freeBILy project. Acta Trop. 2020, $211,105631$. [CrossRef] [PubMed]

48. Frickmann, H.; Lunardon, L.M.; Hahn, A.; Loderstädt, U.; Lindner, A.K.; Becker, S.L.; Mockenhaupt, F.P.; Weber, C.; Tannich, E Evaluation of a duplex real-time PCR in human serum for simultaneous detection and differentiation of Schistosoma mansoni and Schistosoma haematobium infections-Cross-sectional study. Travel Med. Infect. Dis. 2021. [CrossRef] [PubMed]

49. Hahn, A.; Meyer, C.G.; Frickmann, H. Impact of diagnostic methods on efficacy estimation-A proof-of-principle based on historical examples. Trop. Med. Int. Health. 2020, 25, 357-363. [CrossRef] [PubMed]

50. Wichmann, D.; Poppert, S.; Von Thien, H.; Clerinx, J.; Dieckmann, S.; Jensenius, M.; Parola, P.; Richter, J.; Schunk, M.; Stich, A.; et al. Prospective European-wide multicentre study on a blood based real-time PCR for the diagnosis of acute schistosomiasis. BMC Infect. Dis. 2013, 13, 55. [CrossRef] [PubMed]

51. Niesters, H.G.M. Quantitation of viral load using real-time amplification techniques. Methods 2001, 25, 419-429. [CrossRef]

52. Qu, Y.; Tan, M.; Kutner, M. Random effects models in latent class analysis for evaluating accuracy of diagnostic test. Biometrics 1996, 52, 797-810. [CrossRef] [PubMed]

53. Köller, T.; Hahn, A.; Altangerel, E.; Verweij, J.J.; Landt, O.; Kann, S.; Dekker, D.; May, J.; Loderstädt, U.; Podbielski, A.; et al. Comparison of commercial and in-house real-time PCR platforms for 15 parasites and microsporidia in human stool samples without a gold standard. Acta Trop. 2020, 207, 105516. [CrossRef] [PubMed]

54. Henny, J. Constitution d'un centre de ressources biologiques Aspects pratiques. Rev. Epidemiol. Sante Publique 2003, 51, 127-136. [PubMed]

55. De Paoli, P. Bio-banking in microbiology: From sample collection to epidemiology, diagnosis and research. FEMS Microbiol. Rev. 2005, 29, 897-910. [CrossRef] [PubMed]

56. Franco, J.R.; Simarro, P.P.; Diarra, A.; Ruiz-Postigo, J.A.; Jannin, J.G. The Human African trypanosomiasis specimen biobank: A necessary tool to support research of new diagnostics. PLoS Negl. Trop. Dis. 2012, 6, e1571. [CrossRef] 